http://dx.doi.org/10.1590/0370-44672020740058

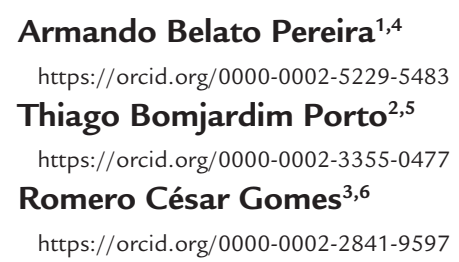

${ }^{1}$ Centro Federal de Educação Tecnológica de Minas Gerais - CEFET-MG, Departamento de Computação e Engenharia Civil, Varginha - Minas Gerais - Brasil.

${ }^{2}$ Centro Federal de Educação Tecnólogica de Minas Gerais - CEFET-MG, Departamento de Engenharia Civil e Meio Ambiente, Curvelo - Minas Gerais - Brasil.

${ }^{3}$ Universidade Federal de Ouro Preto - UFOP, Escola de Minas, Departamento de Engenharia Civil, Ouro Preto - Minas Gerais - Brasil.

E-mails: ${ }^{4}$ armandobelato@hotmail.com, thiago.porto@cefetmg.br, ${ }^{6}$ romeroufop@gmail.com

\title{
Reliability and geotechnical safety applied to deep foundations in precast concrete piles - case study
}

\begin{abstract}
The Brazilian standard pertinent to the design and execution of foundations, NBR 6122/2019, establishes that the safety inspection of foundations of a given project must be conducted based on compliance with specified safety factors. Safety factor verification is imperative to meet regulatory requirements; however, it is not enough to guarantee the safety of a foundation. As there is variability in the resistance and solicitation of the piles that make up a foundation, each safety factor value reflects a failure probability. Therefore, it is fictitious that the use of an adequate safety factor value implies the absence of failure risk. Thus, a reliability analysis, applied to a real building with an access ramp whose foundations are composed of precast concrete piles, based on the probabilistic moments, mean, and coefficient of variation, associated with the variability of pile resistance and solicitation, is presented in this article. The values obtained for the safety factors (2.14 and 1.98 for the building and the ramp foundations, respectively) and failure probabilities (1:2,244 and 1:3,131 for the building and the ramp foundations, respectively) implies that the project in question has an acceptable safety level. This article allows us to conclude that a small variation in the reliability index results in a large variation in failure probability; that a greater global safety factor does not necessarily lead to a lower failure probability and it becomes evident that this reliability analysis is a practical way, to manage the uncertainties inherent in foundation design, allowing rational decision making regarding performance.
\end{abstract}

Keywords: pile foundation, geotechnical bearing capacity, dynamic load testing, safety, reliability.

for a reliability analysis that is appropriate for the quantification of project risk and that is allied to the stipulated safety factors to ensure a certain degree of safety in the design of foundations.

Cintra and Aoki (2010) claim that it is outdated to assume that the safety factors prescribed in the standard guarantee the absence of failure risk in a project. It is also necessary to verify the probability of foundation failure by means of reliability analysis. There will always be a risk of failure in every foundation, and as such, in addition to using the standard safety factors in the design, it is necessary to adopt an acceptable probability of failure.

According to Teixeira et al (2011), in general, civil engineers are aware of nature." Even with such awareness, the 
how uncertainties are important for the design. But in Geotechnics, the uncertainties are either mostly unknown or difficult to measure. That is why, unlike in structural design, the traditional manner that geotechnical engineers introduce the uncertainties in the design is by using high global safety factors (SF) based on experience. However, this manner of treating uncertainties does not give a rational basis to understand their influence on the design.

Some studies highlight the importance of reliability analyses applied to Geotechnical Engineering, which can be mentioned: Duncan (2000), Aoki (2002), Phoon et al (2003), Silva (2003), Silva (2006), Teixeira (2012), Li et al (2015), Souza and Albuquerque (2016), Neves and Reis (2017), Beloni et al. (2017), Naghibi and Fenton (2017), Tang and Phoon (2018), Silva Neto and Oliveira (2018), Haldar (2019), Romanini (2019), Romanini et al. (2019), Velloso (2019) and Tang and Phoon (2019). Duncan (2000) presents that simple reliability analyses, involving neither complex theory nor unfamiliar terms, can be used in routine geotechnical engineering practice. These simple reliability analyses require little effort beyond that involved in conventional geotechnical analyses. Aoki (2002) proposes that the allowed geotechnical pile load be defined according to a probability of failure defined as acceptable, respecting the normative safety factor, and presents a simple and direct methodology for obtaining the probability of piling failure. Phoon et al (2003) mentions that reliability analysis provides a consistent method for propagation of uncertainties and exemplifies the application of mathematical reliability models. In the dissertation by Silva (2003), the proposal presented by Aoki (2002) is applied to verify the safety of foundations based on their ruin probability for a series of foundation designs throughout Brazil. Silva (2006) consolidates the application of Aoki's proposal (2002) in a foundation design of a pier and concludes that the methodology can be applied in the construction of pile foundations, especially to assist in decision making. Teixeira (2012), in her thesis presents sensitivity studies related to reliability and cost analyses in two foundation designs and demonstrates the advantages the use of reliability tools in the decision-making process in the project and design of pile foundations. $\mathrm{Li}$ et al (2015) describes how the code for the design of pile foundations in Shanghai,
China is revised based on the reliability theory. The authors found that the amount of uncertainties associated with the design of piles in Shanghai is less than the typical values reported in literature. Souza and Albuquerque (2016) present a case study in which the safety factor obtained for the pile foundation was 2.32 and the failure probability was $1: 79$, indicating a probable ruin of the foundations. Neves and Reis (2017) present an assessment of the failure probability and the safety of a stretch of foundations in helical piles for towers of power transmission lines. Beloni et al. (2017) evaluate the geotechnical reliability of the pile foundation of a port pier in which the probabilistic distribution of the bearing capacity was evaluated using the concepts of Bayesian theory. The authors also point to the importance of the reliability study for the correct assessment of the safety of any engineering design. Naghibi and Fenton (2017) investigate, based on Monte Carlo simulations, the relationship between the level of reliability of the isolated foundation element and the reliability of the set for deep pile foundations. Phoon and Tang (2018) state that the codes of geotechnical design are migrating to the concepts of design based on reliability (Reliability-Based Design RBD). The aforementioned article collects a large number of axial load tests on helical piles to assess the model's uncertainty. Silva Neto and Oliveira (2018) evaluate the failure probability of two foundation designs on concrete piles and concluded that the failure probability varied considerably for different semi-empirical methods for estimating bearing capacity and demonstrate that even using safety factors recommended by NBR 6122, the works may not have the desired reliability. Haldar (2019) presents an overview of pile foundation design methodologies based on reliability, highlighting the following methodologies: FORM (First-Order Reliability Method), Monte Carlo method and LRFD (Load Resistance Factor Design) and the application of these methodologies in some practical situations. In conclusion, the author highlights the importance of pile foundation projects based on reliability, then considering the variability and spatial correlation of the soil, leading to rational design decisions. Romanini (2019) and Romanini et al. (2019) developed reliability analyzes for pile foundations of two high-standard buildings. Some of the analyzes performed point to a safety factor $(\mathrm{SF})$ close to or below the value of 1.0, indicating that failure is imminent. The authors also conclude that the concept of permissible load currently used, in several situations, as evidenced in the works, does not make the designer aware of all the risks involved and what the real safety of the foundation is, since the safety factor is a situation deterministic, quite different from the reliability index that includes the variability of requests and respective resistances. Velloso (2019) evaluated the failure probability of the foundation design composed of continuous helical piles of a building and found that the resistance variability causes a significant impact on the safety of the foundations and that the overall safety factor predicted by ABNT NBR 6122: 2019 was unsatisfactory to ensure safety within acceptable limits of probability of ruin. Tang and Phoon (2019) based on a database of static load tests developed a reliability analysis for the calibration of disturbance factors in function of the displacements suffered by piles during its execution applied in the LRFD (Load and Resistance Factor method Design).

In this context, this case study consists of a study of geotechnical reliability and safety applied to the deep foundations in precast concrete piles of a project composed of a multipurpose building and its access ramp. Based on the solicitation results obtained for each pile and the mobilized resistance results obtained through dynamic loading tests, it is possible to evaluate the global safety factor obtained for the piling and develop a reliability analysis using the probabilistic moments, the mean and coefficient of variation, associated with the resistance variability and solicitation of these piles. Thus, it will become explicit, in a practical and applied manner that even when fulfilling the safety factor stipulated by NBR 6122 (ABNT, 2019), there is an inherent probability of failure that should be evaluated to determine whether it is acceptable or not by the technical design team of the foundations. A methodology for assessing the safety of the foundations of an enterprise is then presented, based on deterministic analysis in order to comply with current Brazilian code aspects through safety factors (SF) and based on probabilistic analysis in order to evaluate the failure probability associated with the SF obtained are admissible, assisting in the decision-making process in designs. 


\section{Reliability fundamental problem applied to foundation engineering}

The reliability fundamental problem applied to foundation engineering can be expressed as follows: determining the probability that the solicitation (S) of a deep pile foundation element is greater than its geotechnical load capacity (R). In summary, the problem is defining the probability of failure $\left(p_{f}\right)$ of the foundations of a given project.

$$
p_{f}=\int_{0}^{\infty} F_{R}(x) \cdot f_{S}(x) d x
$$

tion function $\mathrm{R}$ until $\mathrm{x}$.

Figure 1 displays the density funcwhere $f_{R}(x)$ is the distribution function $R$ in $x, f_{s}(s)$ is the distribution function $S$ in $x$, and $F_{R}(x)$ is the accumulated distribu- tions $f_{R}(r)$ and $f_{s}(s)$. At point $A, f_{R}(r)$ and
An event considered as a failure occurs when $\mathrm{R}-\mathrm{S}<0$ or $\mathrm{R} / \mathrm{S}<1$. Ang and Tang (1984) mathematically defined the failure probability as

$f_{s}(s)$ are equal, and the area highlighted in black indicates the probability of failure $p_{r}$.

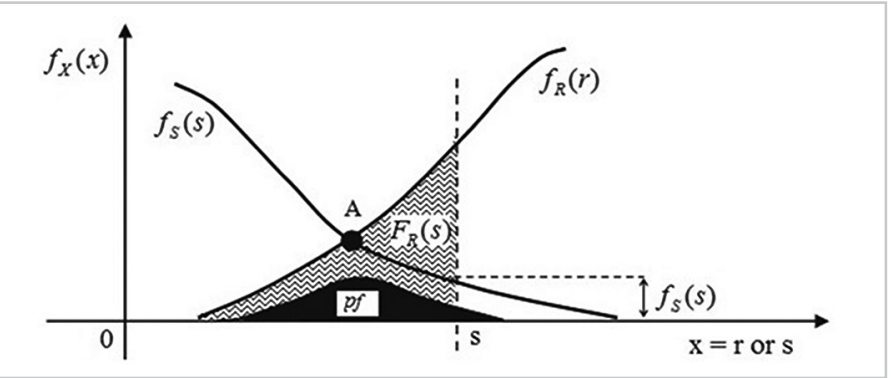

Figure 1 - Density functions $\mathrm{f}_{\mathrm{R}}(\mathrm{r})$ and $\mathrm{f}_{\mathrm{S}}(\mathrm{s})$ (Ang and Tang, 1984, modified by Silva et al., 2016).

Assuming a building foundation is composed of piles of the same cross section, for each isolated foundation element (pile), there is a value for the geotechnical load capacity (R) and a solicitation value (S). Knowing the variability between the $R$ and $S$ values, it is possible to develop a statistical analysis and to plot the resistance probability density $f_{R}(R)$ and solicitation $f_{S}(S)$ curves, as shown in Figure 2.

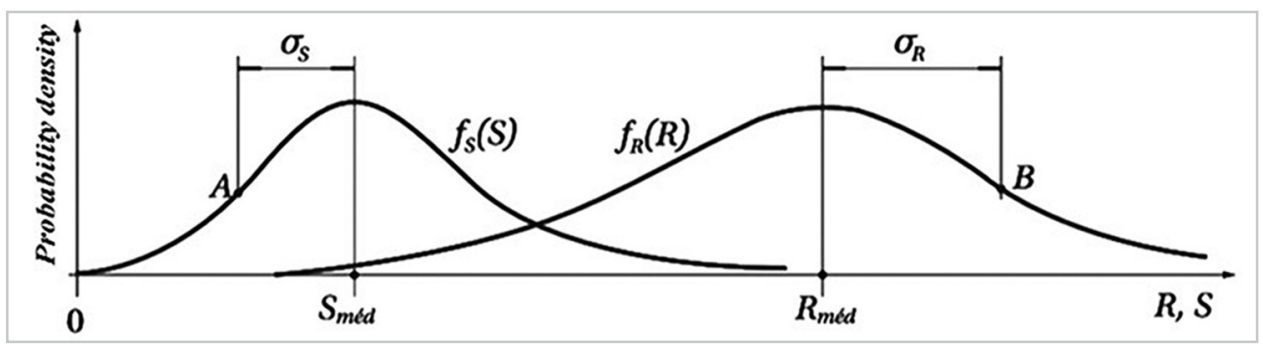

Figure 2 - Probability density of resistance and solicitation (Cintra and Aoki, 2010).

Here, $\mathrm{S}_{\text {med }}$ is the mean pile stress, $\mathrm{R}_{\text {med }}$ is the mean pile resistance or mean pile geotechnical load capacity, $\mathrm{A}$ is the inflexion point of the solicitation curve, $\mathrm{B}$ is the inflexion point of the resistance curve, $\sigma_{S}$ denotes the solicitation standard deviation, and $\sigma_{R}$ denotes the resistance standard deviation.

The dispersion around the mean value of the random independent variables $\mathrm{R}$ and $\mathrm{S}$ is given by their respective standard deviations $\left(\sigma_{R}\right.$ and $\left.\sigma_{S}\right)$. This variability can also be expressed by the data variation in relation to the mean; that is, through the $v_{R}$ (resistance) and $v_{\mathrm{S}}$ (solicitation) coefficients of variation.

The global safety factor (SF) concept considers only the relationship between the mean values of resistance $\left(\mathrm{R}_{\text {med }}\right)$ and solicitation $\left(\mathrm{S}_{\text {med }}\right)$, disregard- ing the variability of geotechnical load capacity and solicitation. In turn, the safety factor indicates not only the distance between the mean values of resistance and solicitation, but also the distance between the relative positions of the resistance and solicitation curves themselves. Therefore, the higher the global safety factor predicted in design, the larger the distance between the $\mathrm{R}$ and $S$ curves.

Cintra and Aoki (2010) concluded that in all staking procedures, once the resistance and solicitation variables are characterized, at each specified safety factor value, a probability of failure is automatically implied. It is a myth that the use of an adequate SF value implies that there is no risk of failure. Therefore, it is essential to analyze whether or not the failure probability is acceptable.

Assuming that the behavior of the distribution curves is normal, with a known mean value, it is enough to consider the coefficient of variation to produce the shape of the curve in the mathematical model. Thus, four variables involved in the problem are identified: the global safety factor (SF), probability of failure $\left(p_{f}\right)$, coefficient of resistance variation $\left(v_{R}\right)$, and coefficient of solicitation variation $\left(v_{s}\right)$. Aoki (2002) presents a methodology based on the probabilistic moments, mean and coefficient of variation, for estimating the probability of failure of a foundation project, as briefly described below.

The safety margin concept $(Z)$ can 
be defined as the difference between resistance $(\mathrm{R})$ and solicitation $(\mathrm{S})$. Thus, a failure or flaw will occur when $Z \leq 0$ because $\mathrm{R} \leq \mathrm{S}$. Figure 3 illustrates this situation, where the shaded area corresponds to the region where $Z \leq 0$.

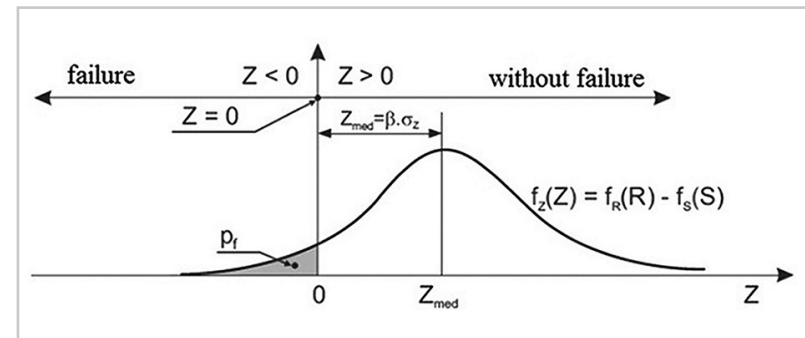

Figure 3 - Safety margin function (Cintra and Aoki, 2010, adapted).

Standard deviation $\sigma_{z}$ of the safety margin function is expressed by

$$
\sigma_{z}=\sqrt{\left(\sigma_{R}\right)^{2}+\left(\sigma_{S}\right)^{2}}
$$

The safety margin mean value $\left(Z_{\text {med }}\right)$ is defined as the difference between mean resistance and mean

Silva (2003) stated that because failure is an event where $Z<0$, the

Beck (2019) characterizes the reliability index or Cornell's reliability index $(\beta)$ as a geometric measure of

solicitation and the safety factor is defined by the ratio between mean resistance and mean solicitation. The

$$
Z_{\text {med }}=S_{\text {med }}(S F-1)
$$

foundation failure probability can be defined based on the safety margin as

$$
p_{r}=P(Z<0)=F_{Z}(0)=\int_{-\infty}^{0} f_{Z}(z) d z
$$

failure probability, which is extremely important in structural reliability. The mean value of the safety margin can be

$$
Z_{\text {med }}=\beta . \sigma_{z}
$$

The safety factor can be calculated by

$$
S F=\frac{1+\beta \sqrt{v_{S}^{2}+v_{R}^{2}-\beta^{2} v_{S}^{2} v_{R}^{2}}}{1-\beta^{2} v_{R}^{2}}
$$

Equation (6) indicates that once the shapes of the R and S curves, defined by their respective coefficients of variation $v_{R}$ and $v_{S}$, are established, the global SF safety factor becomes dependent on the reliability index $\beta$. That is, safety and reliability are mathematically inseparable (Cintra and Aoki, 2010).

Cardoso and Fernandes (2001)

$$
\beta=\frac{1-\frac{1}{S F}}{\sqrt{v_{R}^{2}+\left(\frac{1}{S F}\right)^{2} v_{S}^{2}}}
$$

safety factor of the foundation design relates to the mean safety margin according to

expressed in terms of the unit of standard deviation through the parameter called the reliability index:

developed the following mathematical definition for $\beta$ as a function of the safety factor and of the resistance and solicitation coefficients of variation:

Ang and Tang (1984) demonstrated that the probability of failure $\left(p_{f}\right)$ is a direct function of the reliability index ( $\beta$ ), given by

$$
p_{f}=1-\Phi \beta
$$

where $\Phi$ is the accumulated normal distribution function. 


\section{Case study}

The case study comprising a multipurpose building and an access ramp foundation located in the city of Uberlândia-MG. The foundation design of the multipurpose building used 201 prestressed concrete piles and full section hexagonal piles called P27, P31, and P34.
The letter P indicates polygonal piles, and the number in sequence indicates the length of the piles diagonally in centimeters. The foundation project for the access ramp to the building included 48 precast reinforced-concrete piles, which were circular and had casted sections with a 42-cm external diameter and 25 -cm internal diameter. Figure 4 present the floor plans of the foundation design, highlighting the crowning blocks, which had piles subjected to dynamic loading testing.

For more details on this case study, reading Pereira (2020) is suggested.

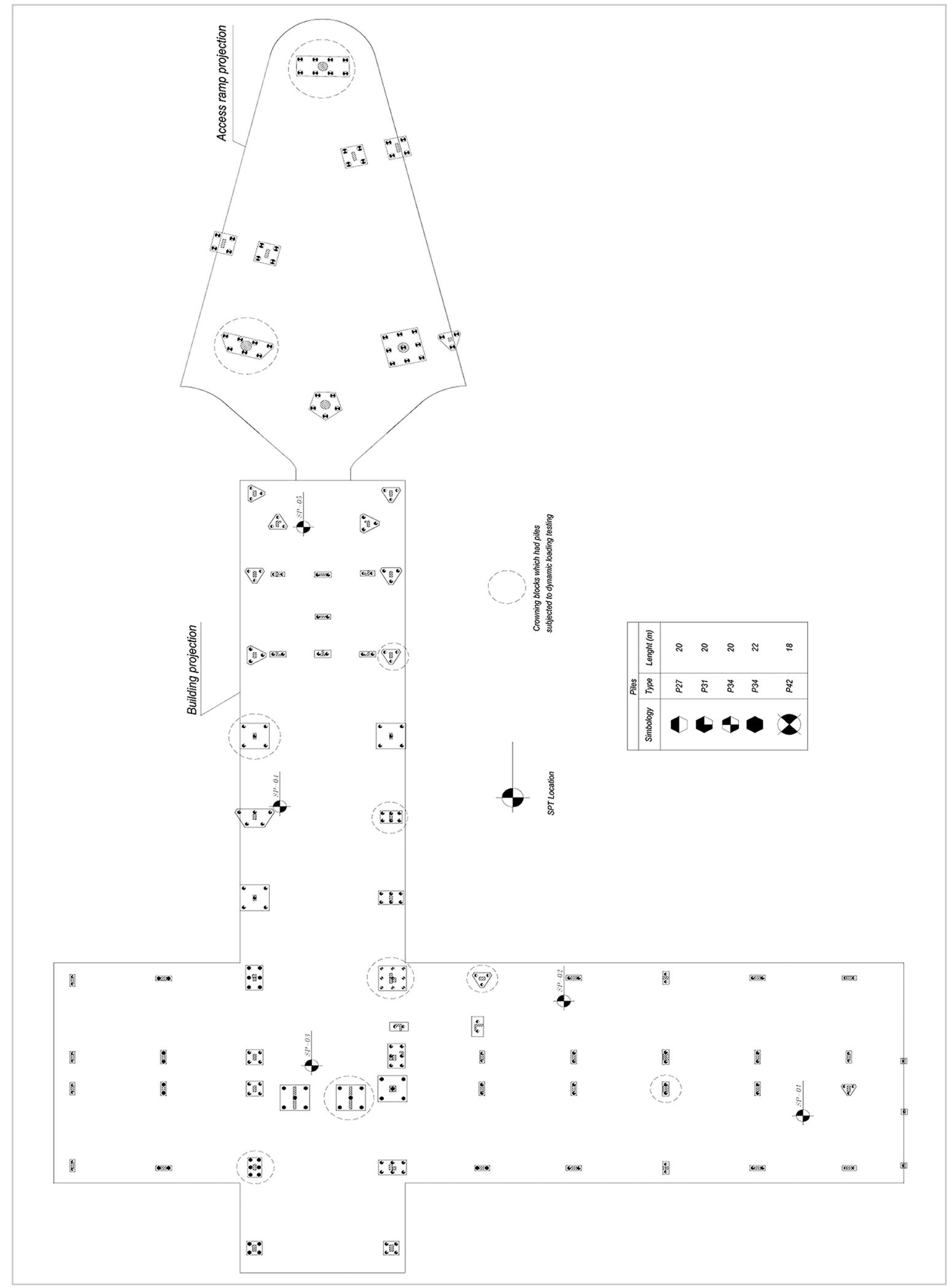

Figure 4 - Floor plan of the foundation design. 
The geological and geotechnical characteristics were determined based on the results of SPT-type percussion drilling. The results of the SPT drilling in five locations (SP-01 to SP$05)$ are shown in Figure 5. The soil is a sandy clay that varies between soft and hard consistencies. These data were applied preliminarily to calculate the bearing capacity of the piles using semi-empirical methods (details in Pereira, 2020).

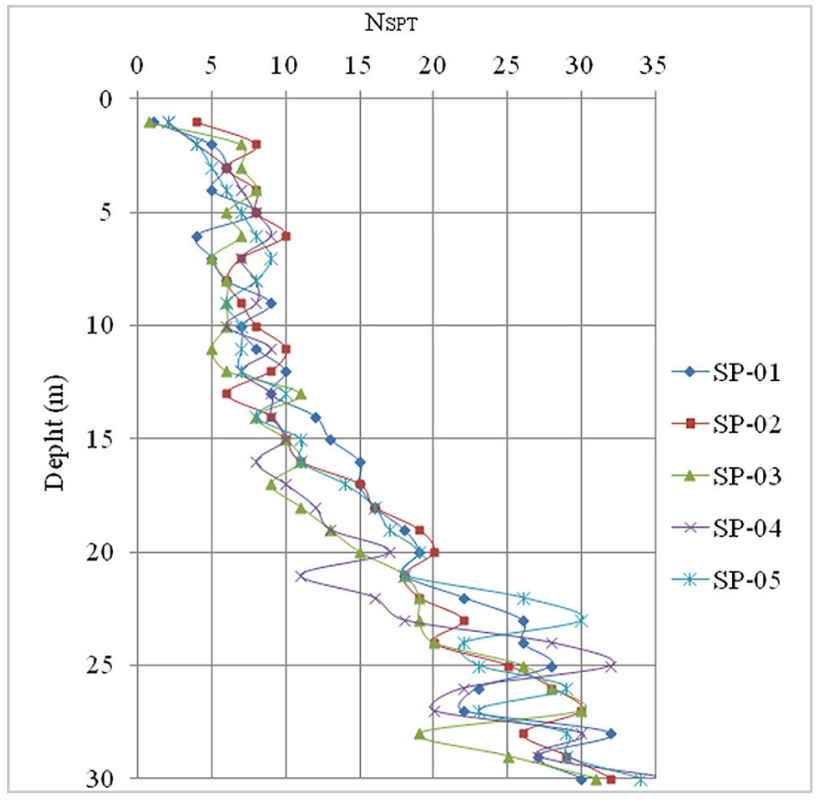

Figure $5-\mathrm{N}_{\mathrm{SPT}}$ 's depth advance.

To evaluate the mobilized load capacity a total of 10 piles composing the studied design were tested by dynamic loading tests using the CAPWAP ${ }^{\circledR}$ system. The relevant data are presented in Table 1.

Table 1 - Results of dynamic loading tests.

\begin{tabular}{|c|c|c|c|c|c|c|c|c|}
\hline Identification of pillar/block & Type of pile & U & A & L & $\mathrm{Pe}$ & $\mathrm{R}_{\mathrm{L}}$ & $R_{p}$ & $\mathrm{R}$ \\
\hline & & $\mathrm{cm}$ & $\mathrm{cm}^{2}$ & $\mathrm{~m}$ & $\mathrm{kN}$ & $\mathrm{kN}$ & $\mathrm{kN}$ & $\mathrm{kN}$ \\
\hline P-42 & P31 & 93 & 624 & 18.5 & 900 & 813 & 115 & 928 \\
\hline P-45 & $\mathrm{P} 27$ & 81 & 474 & 18.5 & 700 & 550 & 124 & 674 \\
\hline $\mathrm{P}-10$ & P34 & 102 & 751 & 20.5 & 1050 & 566 & 335 & 901 \\
\hline P-17-18 & P31 & 93 & 624 & 18.5 & 900 & 706 & 204 & 910 \\
\hline BEL-02 & P34 & 102 & 751 & 20.5 & 1050 & 808 & 448 & 1256 \\
\hline B-40 & P34 & 102 & 751 & 18.7 & 1050 & 862 & 288 & 1150 \\
\hline PR-2 & $\phi 42$ & 132 & $894 *$ & 16.5 & 1300 & 640 & 360 & 1000 \\
\hline P-54 & P27 & 81 & 474 & 18.5 & 700 & 451 & 234 & 685 \\
\hline PR-5 & $\phi 42$ & 132 & $894^{*}$ & 16.5 & 1300 & 546 & 355 & 901 \\
\hline P-62 & P31 & 93 & 624 & 18.5 & 900 & 389 & 271 & 660 \\
\hline
\end{tabular}

* Concrete-filled section area, i.e., disregarding the cast area.

Here, $\phi$ is the pile external diameter $(\mathrm{cm}), \mathrm{U}$ is the perimeter, $\mathrm{A}$ is the cross-sectional area, $\mathrm{L}$ is the nailed length, $\mathrm{P}_{\mathrm{e}}$ is the permissible structural load, $R_{t}$ is the side-mobilized resistance along the pile stem, $R_{p}$ is the mobilized tip resistance at the tip of the pile, and $\mathrm{R}$ is the geotechnical loading capacity of the pile.

\section{Results and discussions}

\subsection{Analysis of solicitation distribution}

The characteristic solicitations acting on the pillar/foundation interface were combined using the load table. The Strut3D module incorporated with the Cypecad software, version 2018, was used for this purpose, allowing the character- istic solicitations assigned to each of the compression rods acting on each pile top to be obtained (details in Pereira, 2020).

Although this study was conducted by working with the pile's geotechnical solicitations and resistances in units of force $(\mathrm{kN})$, for the case of the building foundation, tensile units $(\mathrm{kPa})$ were used. This was due to the diversity of the component pile's dimensions, as a means of eliminating the variable cross section of the pile from the subsequent analyses. 
Therefore, the solicitation $(\mathrm{kN})$ or resistance $(\mathrm{kN})$ value was just divided by the pile cross-section area $\left(\mathrm{m}^{2}\right)$.

The descriptive statistics data for the building and the ramp pile's solicitations are summarized in Table 2.

Table 2 - Descriptive statistics for the building and the ramp piles' solicitations.

\begin{tabular}{c|c}
\hline \multicolumn{2}{c}{ Bulding pile's solicitations } \\
\hline Descriptive statistics & Value \\
\hline Mean $(\mathrm{kPa})$ & 6572.85 \\
\hline Median $(\mathrm{kPa})$ & 6451.80 \\
\hline Minimum value $(\mathrm{kPa})$ & 1725.11 \\
\hline Maximum value $(\mathrm{kPa})$ & 8926.37 \\
\hline Standard deviation $(\mathrm{kPa})$ & 1176.56 \\
\hline Coefficient of variation $(\%)$ & 17.90 \\
\hline
\end{tabular}

\begin{tabular}{c|c}
\hline \multicolumn{2}{c}{ Ramp pile's solicitations } \\
\hline Descriptive statistics & Value \\
\hline Mean $(\mathrm{kN})$ & 478.93 \\
\hline Median $(\mathrm{kN})$ & 504.77 \\
\hline Minimum value $(\mathrm{kN})$ & 30.26 \\
\hline Maximum value $(\mathrm{kN})$ & 627.61 \\
\hline Standard deviation $(\mathrm{kN})$ & 119.05 \\
\hline Coefficient of variation $(\%)$ & 24.86 \\
\hline
\end{tabular}

For statistical analysis, RMarkdown 3.6.1 and Minitab 19 software were used. The hypothesis tests consid- ered were those of Shapiro-Wilk and Kolmogorov-Smirnov which both analyses (building and ramp pile solicitations) converged to the normality of the data. For more details, reading Pereira (2020) is suggested.

\subsection{Analysis of geotechnical load distribution capacities (resistances)}

The data of descriptive statistics of the last eight geotechnical resistances mobilized in DLTs are summarized in Table 3. The hypothesis tests converged to the normality of the data.

Among the piles that made up the foundation of the access ramp to the multipurpose building, only two piles were tested, presenting $901 \mathrm{kN}$ and $1000 \mathrm{kN}$ ultimate mobilized resistances $(\mathrm{kN})$. As highlighted by Silva (2006), it is a common practice to consider the behavior of the pile's resistances as being that of a normal distribution, which was also previously proven for the data related to the multipurpose building. The piles composing the access ramp were subjected to just two dynamic loading tests, which made it impossible to perform tests of the normality hypothesis; therefore, the premise that these data also showed the behavior of a normal distribution was adopted. Descriptive statistics data of the two ultimate geotechnical resistances mobilized in DLTs are presented in Table 3.

Table 3 - Descriptive statistics of building piles' geotechnical resistances.

\begin{tabular}{c|c}
\hline \multicolumn{2}{c}{ Building pile's geotechnical resistances } \\
\hline Descriptive statistics & Value \\
\hline Mean $(\mathrm{kPa})$ & 14092.19 \\
\hline Median $(\mathrm{kPa})$ & 14517.41 \\
\hline Minimum value $(\mathrm{kPa})$ & 10576.92 \\
\hline Maximum value $(\mathrm{kPa})$ & 16724.37 \\
\hline Standard deviation $(\mathrm{kPa})$ & 1933.11 \\
\hline Coefficient of variation $(\%)$ & 13.72 \\
\hline
\end{tabular}

\begin{tabular}{c|c}
\hline \multicolumn{2}{c}{ Ramp pile's geotechnical resistances } \\
\hline Descriptive statistics & Value \\
\hline Mean $(\mathrm{kN})$ & 950.50 \\
\hline Median $(\mathrm{kN})$ & 950.50 \\
\hline Minimum value $(\mathrm{kN})$ & 901.00 \\
\hline Maximum value $(\mathrm{kN})$ & 1000.00 \\
\hline Standard deviation $(\mathrm{kN})$ & 70.00 \\
\hline Coefficient of variation $(\%)$ & 7.36 \\
\hline
\end{tabular}

\subsection{Analysis and discussion of failure probability of the multipurpose building foundation}
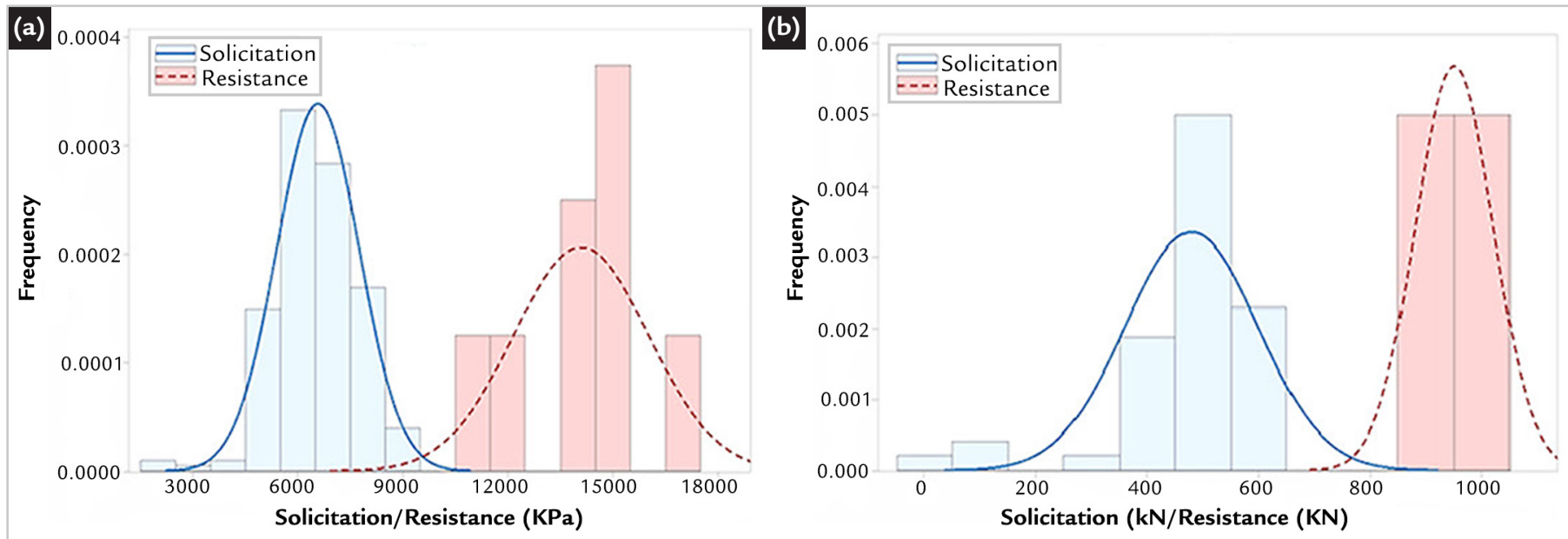

Figure 6 - Normal distribution curves for the solicitation and resistance data: (a) for the multipurpose building; (b) for the access ramp. 
Assuming the Normal distribution of the solicitation and resistance data and plotting the two distributions in the same graph, Figure 6 was obtained, in which there is a clear region of overlap between the solicitation (continuous line) and resistance (dashed line) curves, suggesting that there is a probability of failure implicit in the project to the both cases: multipurpose building and of the access ramp foundations. The area of the mentioned overlapping region corresponds numerically to the failure probability of the foundations as pre- sented mathematically by Equation 1 . The study of the probability of failure of the multipurpose building and of the access ramp foundations followed the mathematical proposal presented at the beginning of this article and are summarized in Table 4.

Table 4 - Analysis of the probability of failure of the multipurpose building and of the access ramp foundations.

\begin{tabular}{c|c}
\hline \multicolumn{2}{c}{ Analysis of the multipurpose building } \\
\hline Parameter & Obtained result \\
\hline Safety factor $(S F)$ & 2.14 \\
\hline Mean safety margin $\left(Z_{\text {méd }}\right)$ & 7519.34 \\
\hline Safety margin standard deviation $\left(\sigma_{z}\right)$ & 2263.01 \\
\hline Reliability index $(\beta)$ & 3.32 \\
\hline Probability of failure $\left(\mathrm{P}_{\mathrm{f}}\right)$ & $1: 2,244$ \\
\hline
\end{tabular}

\begin{tabular}{c|c}
\hline \multicolumn{2}{c}{ Analysis of the ramp } \\
\hline Parameter & Obtained result \\
\hline Safety factor $(\mathrm{SF})$ & 1.98 \\
\hline Mean safety margin $\left(\mathrm{Z}_{\text {méd }}\right)$ & 471.57 \\
\hline Safety margin standard deviation $\left(\sigma_{\mathrm{z}}\right)$ & 138.10 \\
\hline Reliability index $(\beta)$ & 3.41 \\
\hline Probability of failure $\left(\mathrm{P}_{\mathrm{f}}\right)$ & $1: 3,131$ \\
\hline
\end{tabular}

Thus, a probability of failure for the multipurpose building foundation equal to $1: 2,244$ ( 1 in every 2,244 piles) was obtained and the probability of failure for the multipurpose building access ramp foundations was found to be equal to $1: 3,131$ (1 in every 3,131 piles).

Whitman (1984) points out that, particularly in geotechnical engineering, there are no permissible risk patterns and suggests that a possible way forward would be to compile risks observed in natural and human-caused events. The author then presents probability values for annual failure in several civil engineering activities associated with the consequences in financial terms and loss of lives. These results give some indication of the risks accepted by the technical community and society. Therefore, these are situations of permissible risk and show that the probability of annual foundation failure is in the range of $10^{-2}$ to $10^{-3}$, which corresponds to 2.326 and 3.09 reliability indexes, respectively.

Dell'Avanzi and Sayão (1998) stated that the variation range of failure probability and reliability index is very wide. They present typical values adopted in the practice of geotechnical engineering for the probability of failure and reliability index and emphasize that, in the case of foundations, the reliability index used in practice is between 2.3 and 3.0, corresponding to failure probabilities ranging from $10^{-2}$ to $10^{-3}$.

Aoki (2002) underlines that the choice of failure probability or reliability index values depends on the engineering risk that society deems most appropriate. This choice depends on the size of the project, the repair costs, and the consequences of involved material and life losses in the event of the project's foundation failure. This leads to the conclusion that the criterion for adopting the probability of permissible failure in a project is somewhat subjective.

It is worth noting that the Brazilian standard for foundations, NBR 6122 (ABNT, 2019), does not prescribe minimum limits for the probability of failure $\left(p_{f}\right)$ or reliability indexes $(\beta)$ recommended for foundation projects. The explicit adoption of these values is, as a rule, at the discretion of the foundation designer.

Phoon (2004) emphasizes that new design methodologies based on reliability are already widely adopted in structural engineering but are not readily accepted in the geotechnical community due in part to the mathematical robustness of statistical models and the lack of knowledge of probabilistic concepts. Reliability-based designs provide a more consistent means of managing uncertainty but are by no means a perfect solution. Engineering decision making is still indispensable. Reliability analysis eliminates the need for guessing how uncertainties affect foundation performance. The author also solicitates that the use of reliability methods is the next logical step towards greater rationality in projects and their potential benefits should not be discarded because of the reluctance to move beyond the current level of project complexity.

The foundation of the multi-pur- pose building presented a 3.32 reliability index, a 1:2,244 ( 1 in every 2,244 piles) probability of failure, and an overall safety factor of 2.14 . The ramp foundation exhibited a 3.41 reliability index, a 1:3,131 ( 1 in every 3,131 piles) probability of failure, and an overall safety factor of 1.98 (roughly close to 2.0, then considered 2.0), which were within the ranges indicated by Whitman (1984) and Dell'Avanzi and Sayão (1998). As the criterion for adopting the reliability index and the failure probability is considered subjective, with no standardized/regulated values, similarly to Silva (2003), herein, the failure probability value considered acceptable for conventional deep foundations was $10^{-3}$, corresponding to a minimum reliability index of 3.09. These values are in agreement with the mentioned technical literature. This implies that the project in question has an acceptable safety level, respecting the premise described and respecting the safety factor recommended by NBR 6122 (ABNT, 2019), which is a minimum of 2.0 .

Attention is drawn to some limitations of the methodology for calculating the probability of ruin of foundations presented due to simplifications and disregard for some effects, such as: the group effect of the piles, which can influence the resistance mobilized in each pile; the redistribution of efforts by the superstructure that can lead to requests different from those provided for in the foundations; mistakes inherent to design and work execution; noncalculable risks, such as natural and human disasters. 


\section{Conclusions}

The proposal presented in this article for the analysis of the probability of foundation failure, originally presented by Aoki (2002), assumes that the relevant solicitation and resistance data follow a normal distribution. Two hypothesis tests were conducted to assess data normality: Shapiro-Wilk and Kolmogorov-Smirnov.

Regarding reliability and safety issues, both the multipurpose building foundation and the access ramp foundation showed results of failure probability considered acceptable for foundation engineering according to technical literature, e.g. Whitman (1984) and Dell'avanzi and Sayão (1998). The global safety factors met the specifications of NBR

\section{Acknowledgments}

The authors would like to thank the Geotechnical Center of the Ouro Preto Federal University (NUGEO/UFOP, acronyms
6122 (ABNT, 2019). However, it should has mentioned that even when fulfilling normative safety factors, there is a probability of failure inherent to the foundation's design as a result of the variability of solicitations and resistances of the piles composing the foundations.

Furthermore, a small variation in the reliability index $(\beta)$ results in a large variation in failure probability. For example: the reliability index of the access ramp foundation was only $2.7 \%$ higher than the reliability index of the multipurpose building foundation, but in contrast, it had a $28.33 \%$ lower probability of failure.

Another important conclusion is that the results show that a greater global safety factor does not necessarily lead to a lower probability of failure, as it is observed that the building's foundations had a global safety factor about $8 \%$ higher than that of the ramp foundations, however, the probability of failure is approximately $40 \%$ higher than this.

Finally, it was concluded that the reliability analysis based on the probabilistic moments, the mean and coefficient of variation, associated with the variability of the pile's resistance and solicitation, is a practical way, with low mathematical complexity, to manage the uncertainties inherent in foundation design, allowing rational decision making regarding their performance. in Portuguese) and the Federal Center for Technological Education of Minas Gerais (CEFET-MG, acronyms in Portuguese) for supporting this research as well as Consmara Engenharia Ltda. for providing the data relevant to the case study.

\section{References}

ANG, A. H.-S.; TANG, W. H. Probability concepts in engineering planning and design: v. 2 - decision, risk and reliability. New York: Jonh Wiley \& Sons, 1984. 562 p.

AOKI, N. Probabilidade de falha e carga admissível de fundação por estacas. Revista Militar de Ciência e Tecnologia, Rio de Janeiro, v. 19, n. 3, p. 48-64, 2002.

ASSOCIAÇÃO BRASILEIRA DE NORMAS TÉCNICAS. NBR 6122: Projeto e execução de fundações. Rio de Janeiro, ABNT, 2019.

BECK, A. T. Confiabilidade e segurança das estruturas. Rio de Janeiro: Elsevier, 2019.

CARDOSO, A. S.; FERNANDES, M. M. Characteristic values of ground parameters and probability of failure in design according to Eurocode 7. Géotechnique, v. 51, n. 6, p. 519-531, 2001. DOI 10.1680/geot.2001.51.6.519.

BELONI, A. V.; ALVES, A. M. L.; REAL, M. V. Análise de confiabilidade das estacas do cais do Porto Novo de Rio Grande (Brasil) empregando metodologia bayesiana. Geotecnia, Lisboa, v. 141, p. 19-39, 2017.

CINTRA, J. C. A.; AOKI, N. Fundações por estacas: projeto geotécnico. São Paulo: Oficina de Textos, 2010.

DELL'AVANZI, E.; SAYÃO, A. S. F. J. Avaliação da probabilidade de ruptura de taludes. In: CONGRESSO BRASILEIRO DE MECÂNICA DOS SOLOS E ENGENHARIA GEOTÉCNICA, 11., 1998, Brasília. Anais [...]. Brasília: COBRAMSEG, 1998. v. 2, p. 1289-1295.

DUNCAN, J. M. Factors of safety and reliability in geotechnical engineering. Journal of Geotechnical and GeoenvironmentalEngineering,v.126,n.4,p.307-316,2000.DOI10.1061/(ASCE)1090-0241(2000)126:4(307)

HALDAR, S. Reliability-based design of pile foundations. In: ILAMPARUTHI, K.; ROBINSON, G. R. (ed.). Geotechnical design and practice. Singapore: Springer, 2019. p. 225-236.

LI, J. P.; ZHANG, J.; LIU, S. N.; JUANG, C. H. Reliability-based code revision for design of pile foundations: Practice in Shanghai, China. Soils and Foundations, v. 55, n. 3, p. 637-649, 2015. DOI 10.1016/j.sandf.2015.04.014

NAGHIBI, F.; FENTON, G. A. Target geotechnical reliability for redundant foundation systems. Canadian Geotechnical Journal, v. 54, n. 7, p. 945-952, 2017. DOI: https://doi.org/10.1139/cgj-2016-0478.

NEVES, A. M.; REIS, J. H. C. Probabilidade de ruína de estacas helicoidais nas fundações de torres de linhas de transmissão. Geotecnia, Lisboa, v. 139, p. 05-28, 2017.

PEREIRA, A. B. Metodologia semiempirica de cálculo de capacidade de carga geotécnica de estacas com base em dados de SPT extrapolados via krigagem e ensaios de carregamento dinâmico. Tese (Doutorado em Geotecnia) - Núcleo de Geotecnia, Escola de Minas, Universidade Federal de Ouro Preto, Ouro Preto. Em fase de elaboração.

PHOON, K.-K.; BECKER, D. E.; KULHAWY, F. H.; HONJO, Y.; OVESEN, N. K.; LO, S. R. Why consider reliability analysis for geotechnical limit state design? In: INTERNATIONAL WORKSHOP ON LIMIT STATE DESIGN IN GEOTECHNICAL ENGINEERING PRACTICE (LSD2003), 2003. Proceedings [...]. 
[S. l.]: World Scientific, 2003. p. 1-17.

PHOON, K.-K. Towards reliability-based design for geotechnical engineering. Special lecture for Korean Geotechnical Society. Seoul: [s. n.], 2004.

ROMANINI, A. Análise geotécnica em estacas hélice contínua no município de Sinop - MT. 2019. 220 f. Dissertação (Mestrado em Geotecnia) - Núcleo de Geotecnia, Escola de Minas, Universidade Federal de Ouro Preto, Ouro Preto, 2019.

ROMANINI, A.; PORTO, T. B.; CRISPIM, F. A. Análise da probabilidade de falha de uma fundação profunda na região centro-oeste do Brasil. Brazilian Journal of Development, v. 5, p. 31913-31949, 2019.

SILVA, F. C. Análise de segurança e confiabilidade de fundações profundas em estacas. 2003. 252 f. Dissertação (Mestrado em Engenharia Civil: Geotecnia) - Escola de Engenharia de São Carlos, Universidade de São Paulo, São Carlos, 2003.

SILVA, J. L. Metodologia de projeto de fundações por estacas incluindo probabilidade de ruína. 2006. $118 \mathrm{f}$. Dissertação (Mestrado em Geotecnia) - Escola de Engenharia de São Carlos, Universidade de São Paulo, São Carlos, 2006.

SILVA, L. D.; AOKI, N.; FRANCO, Y. B. Use of the order statistics when predicting pile foundation failure probability. DYNA, v. 84, n. 200, p. 247-252., 2016. DOI 10.15446/dyna.v84n200.54867.

SILVA NETO, A. N.; OLIVEIRA, J. T. R. Confiabilidade e segurança de fundações em dois empreendimentos no nordeste do Brasil. Revista de Engenharia Civil, Braga, v. 55, p. 19-28, 2018.

SOUZA, G. G.; ALBUQUERQUE, P. J. R. Avaliação do emprego de prova de carga estática e ensaio de carregamento dinâmico em estacas tipo hélice contínua. In: CONGRESSO BRASILEIRO DE MECÂNICA DOS SOLOS E ENGENHARIA GEOTÉCNICA, 18., 2016, Belo Horizonte. Anais[...]. Belo Horizonte: COBRAMSEG), 2016.

TANG, C.; PHOON, K.-K. Statistics of model factors and consideration in reliability-based design of axially loaded helical piles. Journal of Geotechnical and Geoenvironmental Engineering, v. 144, n. 8, 04018050, 2018. DOI 10.1061/(asce)gt.1943-5606.0001894.

TANG, C.; PHOON, K.-K. Statistical evaluation of model factors in reliability calibration of high displacement helical piles under axial loading. Canadian Geotechnical Journal, v. 57, n. 2, p. 246-262, 2019. DOI 10.1139/cgj-2018-0754.

TEIXEIRA, A. C. M.; CORREIA, A. G.; HONJO, Y. \& HENRIQUES, A. Reliability analysis of a pile foundation in a residual soil: contribution of the uncertainties involved and partial factors. In: INTERNATIONAL SYMPOSIUM ON GEOTECHNICAL SAFETY AND RISK (ISGSR2011), 3., 2011, Munich, Germany. Proceedings [...]. Karlsruhe, Germany: Bundesanstalt für Wasserbau, 2011. p. 323-331.

TEIXEIRA, A. C. M. Reliability and cost models of axial pile foundations. 2012. Tese (Doutoramento em Engenharia Civil / Geotecnia) - Escola de Engenharia, Universidade do Minho, Portugal, 2012.

VELLOSO, H. V. Análise de desempenho dos métodos de capacidade de carga semi-empíricos e avaliação da probabilidade de ruína de uma fundação em estacas hélice contínua. 2019. 199f. Dissertação (Mestrado em Engenharia Geotécnica) - Núcleo de Geotecnia, Escola de Minas, Universidade Federal de Ouro Preto, Ouro Preto, 2019.

WHITMAN, R. V. Evaluating calculated risk in geotechnical engineering. Journal of Geotechnical Engineering, v. 110, n. 2, p.145-188, 1984. DOI 10.1061/(ASCE)0733-9410(1984)110:2(143).

Received: 13 May 2020 - Accepted: 25 August 2020. 